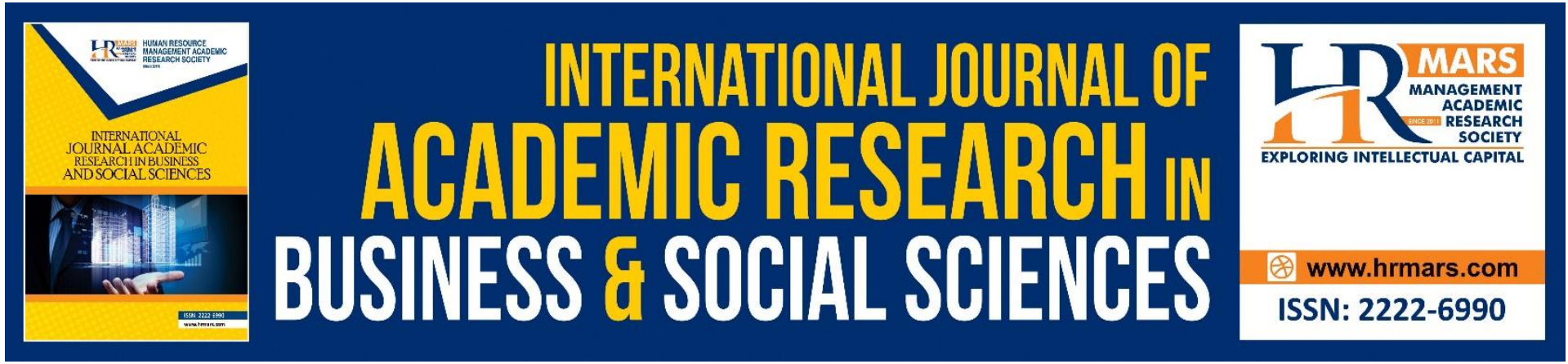

\title{
Speaking For Themselves: The Use of Learning Strategies for Speaking Skills Among Lower Secondary School ESL Learners
}

Wei Zhuang Ooi, Norlisa Abdullah, Sashikala Sarangapani, Sheng Jia Song, Lavanya Vejayan, Harwati Hashim

To Link this Article: http://dx.doi.org/10.6007/IJARBSS/v11-i6/10045

DOI:10.6007/IJARBSS/v11-i6/10045

Received: 15 April 2021, Revised: 18 May 2021, Accepted: 30 May 2021

Published Online: 23 June 2021

In-Text Citation: (Ooi et al., 2021)

To Cite this Article: Ooi, W. Z., Abdullah, N., Sarangapani, S., Song, S. J., Vejayan, L., \& Hashim, H. (2021). Speaking For Themselves: The Use of Learning Strategies for Speaking Skills Among Lower Secondary School ESL Learners. International Journal of Academic Research in Business and Social Sciences, 11(6), 1527-1546.

Copyright: (c) 2021 The Author(s)

Published by Human Resource Management Academic Research Society (www.hrmars.com) This article is published under the Creative Commons Attribution (CC BY 4.0) license. Anyone may reproduce, distribute, translate and create derivative works of this article (for both commercial and non-commercial purposes), subject to full attribution to the original publication and authors. The full terms of this license may be seen at: http://creativecommons.org/licences/by/4.0/legalcode

Vol. 11, No. 6, 2021, Pg. 1527 - 1546

Full Terms \& Conditions of access and use can be found at http://hrmars.com/index.php/pages/detail/publication-ethics 


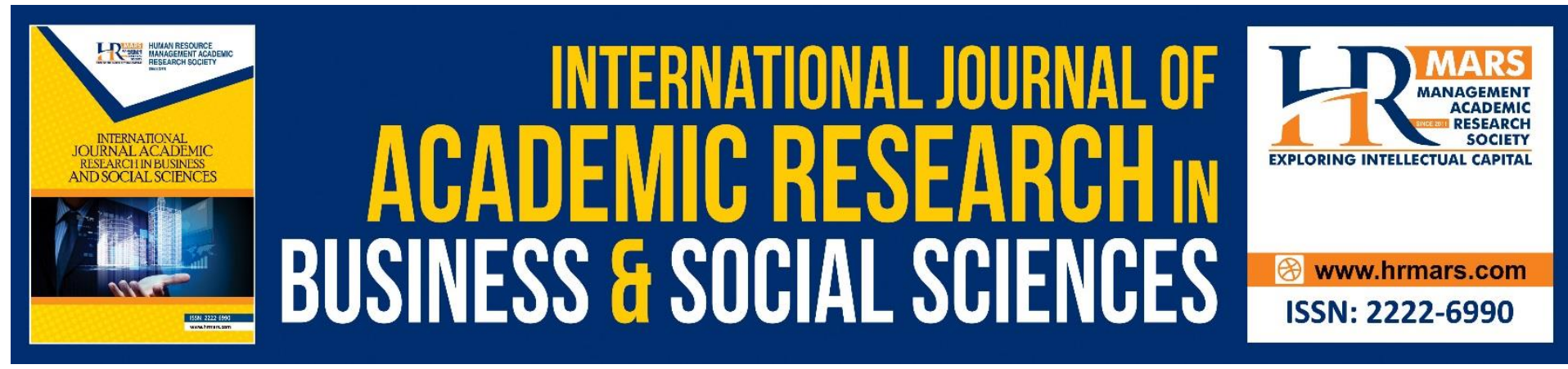

\title{
Speaking For Themselves: The Use of Learning Strategies for Speaking Skills Among Lower Secondary School ESL Learners
}

\author{
Wei Zhuang Ooi, Norlisa Abdullah, Sashikala Sarangapani, \\ Sheng Jia Song, Lavanya Vejayan, Harwati Hashim
}

Faculty of Education, Universiti Kebangsaan Malaysia, 43000 UKM Bangi, Selangor, Malaysia

Email: weizhuangooi93@gmail.com, lysrnz@gmail.com, sashy_59@yahoo.com, shengjia.9324@gmail.com, vejayanl@yahoo.com, harwati@ukm.edu.my

\begin{abstract}
English language has become a universal language to communicate with people worldwide in the era of globalisation as more global citizens take up English as a Second Language (ESL). Yet, ESL learners still face problems in becoming competent speakers of the English language which can impact their communication skills adversely in personal and professional settings. The use of Language learning strategies (LLS) among ESL learners can bring about proficient speaking skills and vice versa. This study aims to find out the extent of ESL learners' use of LLS in relation to their speaking skills. A survey research design was used and data was collected through an online survey questionnaire among Form 2 pupils from a rural Negeri Sembilan secondary school. The 15 close-ended questions adapted from Oxford, Cohen and Chi's Language Strategy Use Survey were formulated to inquire about pupils' use of English speaking learning strategies. The quantitative analysis of the questionnaire results revealed that most pupils never and seldom utilize speaking learning strategies when engaging in English discourse with exception of showing a significant use in the strategy of switching to their native language momentarily. This study of the aforementioned sample demonstrated that most adolescent ESL learners in Malaysian secondary schools use little to none English speaking skill learning strategies and use more of their native language to cope in English conversations. ESL policy makers, educators and researchers are needed to further encourage the ESL learners' active use of LLS for speaking and eventually enhance their speaking skills. Recommendations were provided for future studies in consideration of English language educators and researchers.
\end{abstract}

Keywords: Speaking Skills, Language Learning Strategies, English as a Second Language, Speaking Strategy Use, ESL, LLS

\section{Introduction}

Malaysian education system highlights the English language as one of the important subjects and made it a compulsory subject for pupils in school. English is taught as a second language in schools and is learned by pupils ranging from primary level up to tertiary education. The education ministry has also introduced the Common European Framework for a more 
constructive language learning, teaching and assessment. To support the efforts of educators and pupils, it is important to promote, encourage and support to constantly develop their teaching and learning based on the characteristics, motivations, needs as well as the resources around them (Council of Europe, 2001).

Common European Framework Reference (CEFR) used as the Malaysian syllabus comprises five parts: language awareness - grammar, reading skills, listening skills, writing skills and speaking skills (BPKKPM, 2017). Reading and listening are known as receptive skills because it requires receiving and understanding of information. Likewise writing and speaking are productive skills which enable users of language to contribute to a thought process or practise the language. They are also known as active skills and speaking provides pupils with extra oral practice to communicate effectively (Masduqi, 2016).

Speaking is generally a process that involves two people, where one party is the speaker and the other is the listener. To enable the listener to understand the context of conversation, a speaker should know how to speak eloquently. Speaking English proficiently is the goal for any English as a Second Language (ESL) learner. Hoa and Thao (2020) mentioned that the fundamental skill a learner needs to master is speaking skills. Meaningful sentences or messages could be conveyed if pupils have the language proficiency. Brown et al. (1983) addressed the assumption that there are two parts to language learning which is written and spoken. They mentioned that there are appropriate styles, different registers and structures in the written section. Spoken language focuses more on giving information which means conveying the gist or summary of an issue.

Brown (2001) noted that clustering, reduced forms, redundancy, colloquial language, performance variables, rate of delivery, rhythm, stress and intonation are the factors that affect the difficulty in speaking skill. She further explained that speakers are expected to produce speech in the form of imitation, intensive speaking, responding with short answers, monologues, transactional dialogues and interpersonal dialogues. Thus, for pupils to produce meaningful conversations they should be responsible for their learning process and utilise appropriate language learning strategies.

Language learning strategies (LLS) have been widely recognised as an extremely powerful learning tool since the $19^{\text {th }}$ century (O'Malley \& Chamot, 1990). LLS is a purposeful and conscious mental action by learners to meet their personal chosen goal (Oxford, 1990). It is used in real life context from a casual to a formal situation. Oxford also mentioned that the use of LLS is more flexible, dynamic and interchangeable among learners. Pupils' age, race and motivation could reflect on the language strategy chosen by them. Citra and Zainil (2021) mentioned that age, gender, level of proficiency, motivation, personality and religion are related to the language learning strategies used by pupils. Scholars have their own ways to define the language learning strategies. Language learning strategies are an optional way of making use of available information in improving a second language competence (Bialystok, 1978). Hall (2001) states that learning strategies are behaviours employed by pupils to intervene learning. These definitions directly relate to the scope of our study which is strategies used to practise speaking skills.

Despite various and continuous research being done on the speaking learning strategies (eg: Citra \& Zainil, 2021; Tran \& Tran, 2021; Fathiyah, Amirudin \& Khan, 2020; Saud, 2019; Javed \& Ali, 2018), to the best of our knowledge, there is not much studies exploring the speaking learning strategies among secondary school pupils in the Malaysian context. The results of the study will be beneficial to the teachers and pupils in promoting a better understanding of how users of the language react when they can't think of a word or 
expression, how they engage in conversation and what they do to practise the target language. This result will reflect pupils' awareness of their learning and employed strategies to deliver oral language. Hence, the aim of the research is to investigate to what extent lower secondary school pupils in a school in Malaysia use English speaking learning strategies. This paper will provide ESL researchers, educators and stakeholders useful information about the use of LLS among adolescent ESL learners in Malaysia and suggestions for future research.

\section{Literature Review Speaking}

Speaking is an act of making verbal sounds to engage in conversation, convey or express one's thoughts and feelings in spoken language. Language is a tool for communicating. Effective speaking is an essential life-skill that plays a vital role in school as well as the working world and it is fundamental to succeed in many aspects of life. It is considered that the responsive skills in language learning are reading and listening whereby the other two productive skills that require to be integrated to make communication effective are writing and speaking. Unlike other skills, speaking skill is more complicated because it involves more than pronouncing words. According to Rao (2019), among the four key language skills, speaking is deemed to be the most important skill in learning a foreign or second language. Masuram and Sripada (2020) stated that by enhancing communication skills, talented students get to exhibit their ideas as well as approaches to spoken English allow them to gain and comprehend information from others, express their perspectives, emotions, viewpoint and to resolve problems and issue. Hence, spoken English provides a platform for learners to improve and succeed in their desired field.

In accordance with Stovall (1998), cited in Malihah (2010, p. 88), there are three areas of knowledge involved in speaking. The first area is the mechanics of language elements (pronunciation, grammar, vocabulary) emphasizing on the use of right words in the right order with the correct pronunciation. Next, it is followed by the functions of language. For instance, knowing how to change information and giving the clarity of an essential message. Lastly, the socio-cultural norms such as turn-taking, rate of speech, length of pauses between speakers, relative roles of participants and understanding how to take into account who is speaking to whom, in what circumstances, about what, and for what reason.

As in the Malaysian context, English is the second important language and it is being taught as one of the compulsory subjects which is being taught and tested in the Malaysian education system from Standard One to Form Five. Despite eleven years of learning, many students are still finding it challenging to master the language and their level of proficiency is low for beginners due to lack of practice, especially outside of the classroom. As a solution to all situations, the Ministry of Education of Malaysia implemented the Common European Framework of Reference (CEFR) in order to provide support for students to understand and also improve the levels of language proficiency by skills. As a result, the positive outcomes of CEFR are observable as students now progress through levels when they were given the thorough guideline to set their goal. In contrast, most of the teachers suggest that there should be a teacher training program to teach CEFR and on how to use the reference tool more effectively. This is because teachers aren't familiar with the foreign content and it is less relatable to Malaysia context. As a result, it can be said that Malaysia's education system is still struggling to give a reliable program that encourages students to learn the language and firmly inculcates them with language learning skills by actively participating in the learning process without failing. 


\section{Language Learning Strategies}

Learning is a process of acquiring knowledge, facts, skills, and procedures to be applied when required whereby strategy is the general idea which is intended to achieve for a long period of time. Learning strategies are significant for pupils to improve the quality of language learning. Subramaniam and Palanisamy (2014) briefly summarized the history of language learning strategies by stating that when the acquaintance of second language has increased evidently during the 1970s, teachers and researchers realised that there were no research findings and teaching methodologies that could pave the way in an era of universal success in teaching a second language. Thus, language learning strategies have been an emphasis of research for many years now. Likewise, teaching requires one to consider and understand the value of differentiated instruction, while learning requires learners to broaden and apply suitable strategies when learning a language in order to develop to their full potential. By the same token, learning strategies build confidence exceedingly rather than getting learners to be stressed out by trying to fit a standard mould. Environment, level of motivation and comprehension play an immense role in language learning because learners acquiring a second or foreign language consume more time as they didn't grow up in the particular language speaking environment and vice-versa. Hence, students should be mindful of language learning strategies and put them into practice.

Numerous researchers studied and did research on language learning strategies and the studies were conducted to analyse the language learning strategies used by pupils and the effectiveness of the approaches in improving and developing their speaking skill. Rubin (1987), Oxford (1990) and O'Malley and Chamot (1990) are some of the researchers who have classified language learning strategies. According to Rubin (1987), as cited in Zare (2012), there are three main groups of language learning strategies which are learning strategies, communication strategies, and social strategies. Oxford (1990) differentiated language learning strategies into two namely direct and indirect strategies. Oxford (1990) divides language learning strategies into six groups: memory strategies (remembering and recalling new information), cognitive strategies (comprehending and producing new language by many different means), compensation strategies (overcoming knowledge gaps and continuing to communicate authentically), affective strategies (developing the self-confidence), metacognitive strategies (problem solving and taking control of their learning) and social strategies (increasing interaction and more empathetic understanding). Direct strategies refer to the use of language in a specific manner while indirect strategies do not involve using the language (Oxford 1990). On the other hand, O'Malley and Chamot (1990) demonstrated there are three types of language learning strategies including metacognitive strategies, cognitive strategies, and socio-affective strategies.

Strategies are pivotal in the process of learning and irrefutable worth every effort. According to the study carried out by Saputra and Subekti (2017), students who apply more speaking learning strategies to develop and strengthen their speaking skills have the tendency to score well in speaking skills. This explains that students should be aware that applying the language learning strategies can be rewarding and it categorises them as a good language learner.

\section{Methodology \\ Research Design}

In this study, a quantitative survey research design was used. Quantitative survey research enables the collection of numeric data from a small group through their responses from a set 
of questionnaires to describe trends in practices or attitudes of a certain population (Creswell, 2012). Thus, being one of the main reasons why this research design was chosen. The results obtained from a quantitative study will explain whether it is either supporting or refuting what is predicted of the study (Creswell, 2012). This survey research method would be able to gain information on the extent to which speaking learning strategies are used by the selected pupils.

\section{Research Sample}

The research respondents were chosen from a rural secondary school, in Negeri Sembilan, consisting of Malay, Indian and Indigenous pupils. The majority of pupils in the population are of Malay and Indigenous backgrounds. 44 Form 2 lower secondary school pupils took part in this study. Their English Language proficiency level ranges from basic to independent users of English according to the Common European Framework (CEFR) language proficiency chart found in Standard Based Curriculum for Secondary Schools (KSSM) Form 2 document (BPKKPM, 2017). Purposive sampling was carried out to choose participants of the research. Battaglia (2008) mentioned that purposive sampling's main objective is to create a sample that is logically assumed to represent the population. The selection of a purposive sampling, which is a non-probability sampling, is based on the characteristics of a population and objective of the study (Crossman, 2020). Similarly, lower secondary pupils from the Negeri Sembilan school were chosen as the sample to achieve the aim of the research.

\section{Research Instrument}

According to Creswell (2012), an instrument is needed in quantitative data instruction to evaluate the variable of the study, as well as containing specific questions and responses to measure or document quantitative data. This research used a survey questionnaire to collect data. The research instrument was adapted from the Speaking Strategy Use section of Language Strategy Use Survey by Oxford et al. (2002). According to Cohen and Weaver (2005), the Language Strategy Use Survey was found to be both reliable and valid based on a confirmatory factor analysis, consisting of a 300 pupils sample. The purpose of the questionnaire is to explore one's experience as a language learner and to help identify strategies in mastering a language (Cohen \& Weaver, 2005). Hence, this survey questionnaire collected data on the participants' speaking learning strategies used. 15 questions were formulated and translated into the Malay language which was commonly used by the participants so they were able to give accurate responses. The 15 items available in the survey were divided into three sections, as shown below:

\begin{tabular}{cc}
\hline Section & Description \\
\hline Section 1: Item 1 - 3 & Strategies to Practise Speaking \\
Section 2: Item 4 - 9 & Strategies to Engage in Conversations \\
Section 3: Item 10 - 15 & Strategies for When I Can't Think of a \\
Word or Expression
\end{tabular}

Table 1: Description for each section of the survey questionnaire 
This research questionnaire required pupils to respond to each statement using a four-point Likert scale. The description of the Likert scales are as follows:
Scale
Description

1

I never use the strategy.

2

I seldom use the strategy. (1-2 times a week)

3

I sometimes use the strategy. (3-4 times a week)

4

I often use the strategy. (More than 4 times a week)

Table 2: Likert scale description for each Language Strategy Use inventory

\section{Data Collection Procedure}

The study was carried out in a quantitative method using a survey questionnaire. The survey questionnaire was distributed to the participants in the duration of one week. It was administered to all the 44 participants via Google Form Document online through WhatsApp, an instant messaging application that all participants were familiar with using. Participants were required to answer all the questions on the online Google Form individually to describe their speaking learning strategies. The data collected was gathered through the instrument by the end of the week.

\section{Data Analysis}

Frequency counts collected from the survey questionnaire regarding participants' practice of English speaking learning strategies were analysed descriptively. The data collected from the survey questionnaire responses were analysed in percentages. The percentage of each item, according to the Likert scales, was then calculated and presented in the form of a table. Lastly, the overall percentage for each section was interpreted into a pie chart. The participants' responses describe the extent to which they use language learning strategies in relation to their speaking skills.

\section{Findings \& Discussion}

The findings of this research will be discussed based on the three categories of speaking learning strategies. Discussion of strategies employed by pupils will be further elaborated after the findings. 


\section{i) Speaking Learning Strategies}

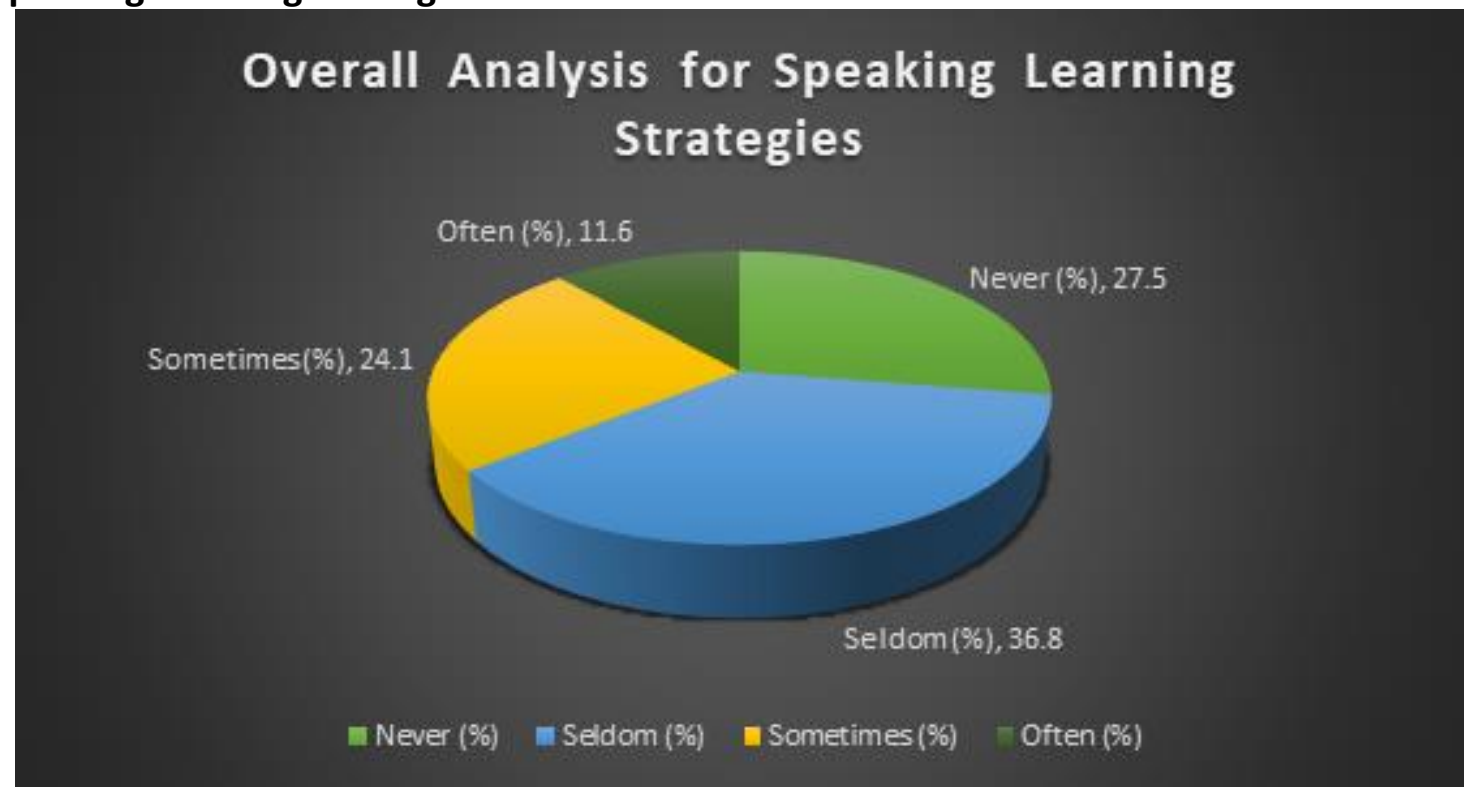

Figure 1: Overall Analysis for Speaking Learning Strategies

Regardless of the type of English speaking learning strategy, Figure 1 depicts an overview of how frequent pupils practise these strategies in a week. Evidently, the majority $(36.8 \%)$ of the pupils seldom apply speaking learning strategies in their life. The order is followed by pupils who never applied speaking learning strategies in their life. It was totalled at $27.5 \%$. With a nearly similar percentage, $24.1 \%$ pupils sometimes employ these strategies. $11.6 \%$ of pupils reported that they often used speaking learning strategies, which was the lowest percentage achieved overall. Based on the results, we can conclude that most pupils do not habitually practise speaking learning strategies.

\section{ii) Strategies to Practise Speaking}

\begin{tabular}{lcccc}
\multicolumn{1}{c}{ Item No. } & Never (\%) & Seldom (\%) & Sometimes (\%) & Often (\%) \\
\hline Item 1: Practise saying new expressions to myself. & 14 & 43 & 39 & 4 \\
\hline $\begin{array}{l}\text { Item 2: Practise new grammatical structures in different } \\
\text { situations to build my confidence level in using them. }\end{array}$ & 27 & 32 & 34 & 7 \\
\hline $\begin{array}{l}\text { Item 3: Think about how a native speaker might say } \\
\text { something and practice saying it that way. }\end{array}$ & 22 & 39 & 25 & 14 \\
\hline
\end{tabular}

Table 3: Frequency Percentages of Pupils Use of Strategies to Practise Speaking

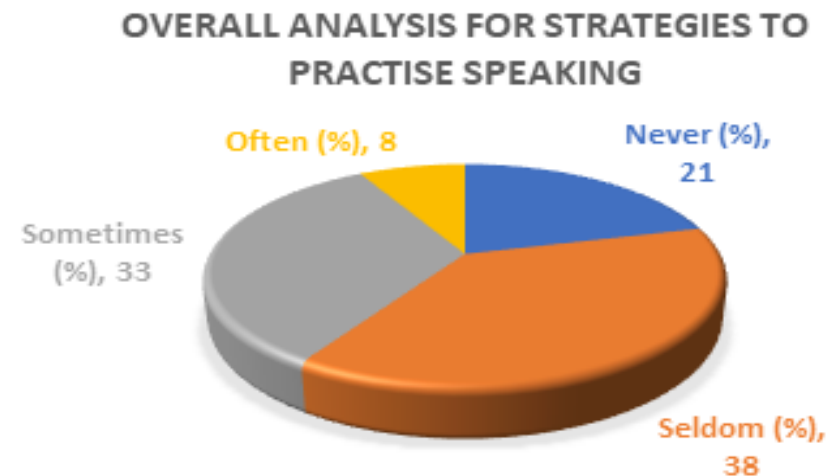

Figure 2: Overall Analysis For Strategies to Practise Speaking 
Overall, very few pupils use strategies to practise speaking often. Based on Figure 2, there were $8 \%$ of them. The most often used strategy to practise speaking was Item 3 which was thinking about how a native speaker says something and practises saying it that way. Even though Item 3 had 14\% of pupils often using the strategy (Table 3), there was still a drastic difference compared to frequency percentages of the other strategies applied. This reflects the remaining 2 strategies as well, and one of them achieved the lowest frequency percentage, $4 \%$ which shows that pupils were less likely to practise saying new expressions to themselves habitually or often (Item 1).

In contrast to other frequency of strategy application, more than $30 \%$ of participants answered "seldom" on the use of all three sub-strategies in Table 3 and had accumulated an average of $38 \%$ based on Figure 2 . This pointed out the fact that the pupils were not keen on applying strategies to practise speaking. In addition, about $27 \%$ of pupils never practise new grammatical structures in different situations to boost their confidence level in using them (Item 2).

From the results above, pupils should be more aware of the speaking learning strategies in taking initiatives to learn new expressions (Item 1) and grammatical structures (Item 2). Being accustomed to people around with a local English accent, it could be an underlying reason why pupils considered using less strategies involving thinking about how a native speaker says something and practises saying it (Item 3 ).

\section{iii) Strategies to Engage in Conversations}

\begin{tabular}{lcccc}
\multicolumn{1}{c}{ Item No. } & Never (\%) & Seldom (\%) & Sometimes (\%) & Often (\%) \\
\hline Item 4: Plan out what I want to say in advance. & 29.5 & 29.5 & 32 & 9 \\
\hline $\begin{array}{l}\text { Item 5: Ask questions as a way to be involved in the } \\
\text { conversation. }\end{array}$ & 23 & 41 & 18 & 18 \\
\hline Item 6: Able to continue the conversation. & 34.1 & 43.1 & 11.4 & 11.4 \\
\hline Item 7: Try topics even when they aren't familiar to me. & 23 & 57 & 16 & 4 \\
\hline Item 8: Encourage others to correct errors in my speaking. & 32 & 48 & 16 & 4 \\
\hline $\begin{array}{l}\text { Item 9: Try to imitate native speakers' language patterns } \\
\text { used in conversation through any possible exposure. }\end{array}$ & 30 & 36 & 23 & 11 \\
\hline
\end{tabular}

Table 4: Frequency Percentages of Pupils Use of Strategies to Engage in Conversations

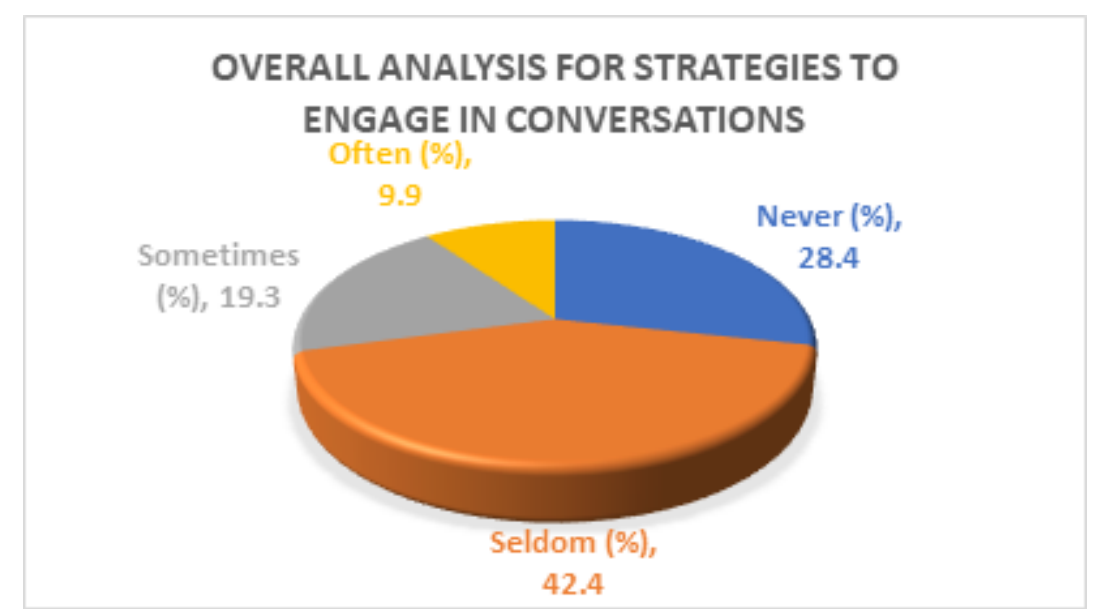

Figure 3: Overall Analysis for Strategies to Engage in Conversations

Looking into strategies to engage in conversation, more than half, an accumulation of $57 \%$ pupils (Table 4 ), seldom try unfamiliar topics (Item 7 ). It was the highest percentage 
achieved among all the categories' items and frequency. Furthermore, about $23 \%$ of the pupils never tried Item 7 . This prominently demonstrated that the pupils lacked habits in trying out unfamiliar topics. According to a research conducted by Cao et al. (2021), pupils who learn English as foreign language are reluctant to speak when they lack related topical knowledge discussed. This clarifies why this strategy was not favoured by most of the pupils.

Besides that, more than $60 \%$ of pupils never and seldom carry out the strategies to involve themselves in conversation. Based on Figure 3, $70.8 \%$ of them belonged to these frequencies. Pupils, especially, had little to no experience in continuing the conversation (Item 6), trying unfamiliar topics (Item 7), and encouraging others to correct errors in their speaking (Item 9).

On the other hand, a strategy that most pupils applied "sometimes" was planning out what they want to say in advance (Item 4), whereas the most applied one in the "often" frequency was asking questions as a way to be involved in the conversation (Item 5).

Lastly, the least people, about $5 \%$ of pupils often tried topics even when they aren't familiar to them (Item 7), or often encouraged others to correct errors in their speaking (Item 8) to engage in English conversations.

\section{iv) Strategies for When I Can't Think of a Word or Expression}

\begin{tabular}{|c|c|c|c|c|}
\hline Item No. & Never (\%) & Seldom (\%) & Sometimes (\%) & Often (\%) \\
\hline Item 10: Ask for help from my conversational partner. & 20 & 37 & 18 & 25 \\
\hline $\begin{array}{l}\text { Item 12: Use words from my own language, but say it in a } \\
\text { way that sounds like words in the target language. }\end{array}$ & 45 & 36 & 14 & 5 \\
\hline $\begin{array}{l}\text { Item 14: Use gestures as a way to try and get my meaning } \\
\text { across. }\end{array}$ & 39 & 32 & 13 & 16 \\
\hline $\begin{array}{l}\text { Item 15: Switch back to my own language momentarily if I } \\
\text { know that the person l'm talking to can understand what is } \\
\text { being said. }\end{array}$ & 11.4 & 11.4 & 27.2 & 50 \\
\hline
\end{tabular}

Table 5: Frequency Percentages of Pupils Use of Strategies for When I Can't Think of A Word or Expression

\section{OVERALL ANALYSIS FOR STRATEGIES FOR WHEN I CAN'T THINK OF A WORD OR EXPRESSION}

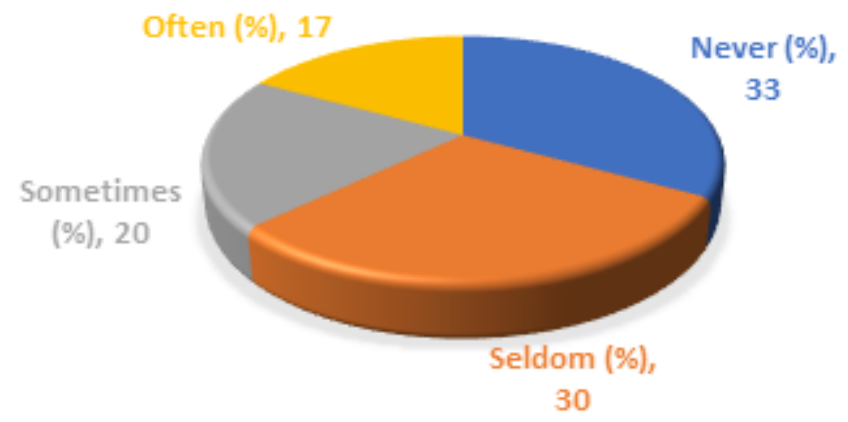

Figure 4: Overall Analysis For Strategies for When I Can't Think of A Word or Expression

Among all the strategies in Table 5, most pupils (50\%) never looked for a different way to express the idea, like using a synonym (Item 11 ). It is then followed by $45 \%$ of pupils who 
never use words from their own languages, but say them in a way that sounds like words in the target language (Item 12).

On the contrary, Item 15 was the only strategy practised often by at least half of the pupils, $50 \%$. It is evident that pupils often switched to their native languages momentarily if they know the person they are talking to can understand what is being said. Indirectly, this reveals that pupils feel more comfortable and have a higher tendency to speak in their mother tongue naturally whenever there are chances. With people around who similarly learn English as their second language, the inclination becomes even higher. (Cao et al., 2021; Mridha, 2020).

According to Figure 4, "never" percentage placed the highest among all the frequencies. This indicated that most pupils never implement strategies for when they can't think of a word or expression in comparison with the strategies in Category 1 and Category 2. Subsequently, "seldom" covered up a total of $30 \%$, which has little difference than "never". Among all the strategies utilized seldom, most pupils would ask help from their conversational partners (Item 10).

Then, very few people, $5 \%$ of them often looked for a different way to express the idea, like using a synonym (Item 11), often used words from their own languages, but say them in a way that sounds like words in the target language (Item 12) and, often make up new words or guess if they don't know the right ones to use (Item 13). When pupils lack English vocabulary knowledge, it is less likely they would express their thoughts (Cao et al., 2021).

To sum up, from all the results above, it is obvious that the Form 2 pupils do not often apply most of the English speaking learning strategies in their daily lives. Additionally, the only prominent strategy used often is too related to switching back to one's mother tongue. This shows an urgency for pupils' awareness on the importance of learning to speak English more efficiently and strategically.

When pupils seldom expose themselves to speaking learning strategies, it could signify pupils lacking the curiosity, motivation and courage to try out something new. In order to realise this, Asmin (2020) emphasised the significance of pupils' intellectual curiosity and learning motivation to increase their creativity, critical thinking skill and academic performance. This can be done through active participation in asking and responding to while learning. In relation to that, Bandura (1994) and Khatib and Thangaveloo (2021) proposed that high aspiration and strong commitment to goals, also known as strong personal efficacy beliefs are vital. It is evident that English-speaking self-efficacy beliefs and English speaking performance are interrelated. Therefore, it is necessary for pupils to possess an active learning speaking attitude. Additionally, efforts by pupils or any related authority to increase their closeness to the English language in daily activities are effective too (Husna, 2021).

As the pupils interviewed are of average or low English proficiency level, fear of making mistakes along with the consciousness of their own English speaking shortcomings could be the hindrance too. In a study conducted by Doyman and Yumru (2020), Mridha (2020), and Al Nakhalah (2016), it is proven that pupils who studied English as foreign language encountered anxiety when speaking it. The reason behind explains the results found in this study where others' attitudes towards their English speaking flaws matters (Liandika et al., 2021). Hence, there is a need to cultivate their self-confidence and motivation to speak more regardless of the mistakes made, so they would make more effort in speaking a second language (Muamar et al., 2019; Syafitri et al., 2019).

Lastly, Canale and Swain (1980) had also proposed a Communicative Competence 
Model that proclaims that speakers become more capable in speaking with four competence areas. These areas are grammatical competence (using the right grammatical structure), sociolinguistic competence (producing culturally and socially suitable language), strategic competence (providing solution to utterances miscommunication), and discourse competence (constructing coherent and cohesive sentences). Despite pupils making progress on their own to improve speaking, it is also the relevant authorities like parents or teachers' responsibilities to be knowledgeable and concerned of such models or strategies listed above. Consequently, they might aid and speed up the progress of pupils learning to speak English as their second language more proficiently.

\section{Implications and Conclusion}

This study concluded that lower secondary school ESL learners were not familiar with using speaking learning strategies when opportunities for English speaking arise. Majority of pupils seldom or never used the three types of strategies for the purpose of practising speaking, engaging in conversations and when they can't express themselves fully in the target language whereas less than $40 \%$ of the pupils reported they sometimes and often use the strategies. However, most pupils admitted they would switch to using their mother tongue temporarily when having exchanges in English in the event of speaking to people who know their native language. Pupils' underwhelming use of speaking learning strategies can be attributed to their lack of topical knowledge, limited English vocabulary size, low confidence or high anxiety in speaking, their minimal exposure to the English language and lack of immersion in English speaking environment throughout their daily lives. This suggested that pupils were not equipped with sufficient English knowledge such as grammar, content words or language learning strategies along with good support from educators and the school academically to use speaking learning strategies. Hence, from the study, the secondary school ESL learners in Malaysia do not use LLS for the practice and development of their own English speaking skills as ideally as one would presume. It is recommended for policy makers, school administration and ESL educators to provide pupils a safer and positive space for them to actively practise English with speaking strategies in mind. From the research data itself, ESL educators and researchers can pinpoint ESL learners' need for English speaking strategies then plan for more efficient interventions. Consequently, pupils would become more motivated to improve their English speaking skills and self-efficacy. Nevertheless, this study entails further research on the use of strategies for learning English speaking among ESL learners. For one, the adapted survey questionnaire can be applied to study ESL learners of different demography on their utilization of speaking strategies including younger learners, higher proficiency ESL learners or learners located in urban schools for further exploration. It is also recommended for prospective researchers to include other research methods like classroom observations, teacher interviews with the survey to acquire an even thorough information about learners' speaking strategies use from various perspectives.

On a final note, this study provided insights regarding the use of LLS for English speaking skills among Malaysian lower secondary school ESL learners. The result from the research consider possibilities of adolescent ESL learners especially in Malaysia and other ESL countries to have lesser awareness about English speaking skills LLS where the aforementioned learners are not knowledgeable or skilful in learning to speak English in situations such as engaging in conversations of the target language, reacting to words or expressions they do not know and practising the spoken target language. Thereupon, this study contributes knowledge concerning the characteristics of ESL learners who are weaker 
in English speaking skills to a certain degree. The study also suggests a lack of involvement and awareness by various groups including family and teachers in supporting adolescent ESL learners' use of related LLS to establish good foundations of learning to speak English. ESL researchers and educators alike can utilize elements of this study in grasping learners' specific needs of LLS for speaking based on the formulated research survey while identifying plausible causes of ESL learners' lower English speaking performance in relation to their learning background demographically. Various guidelines and further research can be planned and carried out in exploring or developing learners' LLS for English speaking skills as recommended previously.

\section{Corresponding Author}

Harwati Hashim is a senior lecturer at the Centre of Innovation in Teaching \& Learning, Faculty of Education, Universiti Kebangsaan Malaysia (UKM).

Contributors/ Acknowledgement: All authors contributed equally to this work.

\section{References}

Al Nakhalah, A. M. M. (2016). Problems and difficulties of speaking that encounter English language students at Al Quds Open University. International Journal of Humanities and Social Science Invention. http://www.ijhssi.org/papers/v5(12)/version3/05120396101.pdf.

Asmin, A. I. (2020). Observing the intellectual curiosity of English education students in the class. IDEAS: Journal on English Language Teaching and Learning, Linguistics and Literature, 8(1), 46-58.

Bahagian Pembangunan Kurikulum Kementerian Pendidikan Malaysia (BPKKPM). (2017). Dokumen Standard Kurikulum dan Pentaksiran Bahasa Inggeris Tingkatan Dua.

Bandura, A. (1994). Self-efficacy. Encyclopedia of Human Behavior, Vol. 4, pp. 71-81. New York: Academic Press.

Battaglia, M. (2008). Purposive sample. In P. J. Lavrakas (Ed.), Encyclopedia of survey research methods (pp. 645-647). SAGE Publications, Inc. https://www.doi.org/10.4135/9781412963947.n419

Bialystok, E. (1978). A theoretical model of second language learning. Journal of research in language studies, 28 (1), 69-83.

Brown, G. (2001). Teaching by principles: An interactive approach to language pedagogy (Vol 2). Pearson education.

Brown, G., Gillian, B., Brown, G. D., \& Yule, G. (1983). Teaching the spoken language (Vol. 2). Cambridge university press.

Canale, M., \& Swain, M. (1980). Theoretical bases of communicative approaches to second language teaching and testing. Applied Linguistics, 1(1): 1-47.

Cao, C. M. K., Dan, T. C., Thanh, C. V., Da, T. C., \& Chau, P. T. H. (2021, January). ELF Students' Speaking Skills: Difficulties and Solutions: A Case at Can Tho University, Vietnam. In Proceeding the First International Conference on Government Education Management and Tourism (Vol. 1, No. 1, pp. 402-412).

Citra, M., \& Zainil, Y. (2021). Language Learning Strategies in Speaking Classroom Activity: Extrovert and Introvert Learners. In Ninth International Conference on Language and Arts (ICLA 2020) (pp. 161-166). Atlantis Press.

Cohen, A. D., Oxford, R. L., \& Chi, J. C. (2002). Language strategy use survey. Minneapolis, 
MN: Center for Advanced Research on Language Acquisition, University of Minnesota.

Cohen, A. D., \& Weaver, S. J. (2005). Styles and strategies-based instruction: A teachers' guide. Minneapolis, MN: Center for Advanced Research on Language Acquisition, University of Minnesota.

Council of Europe. (2001). Common European framework of reference for languages: Learning, teaching, assessment. Cambridge, U.K: Press Syndicate of the University of Cambridge.

Creswell, J. W. (2012). Educational research: Planning, conducting, and evaluating quantitative and qualitative research (4th ed.). Boston: Pearson Education

Crossman, A. (2020, March 19). Understanding purposive sampling. ThoughtCo. https://www.thoughtco.com/purposive-sampling-3026727

Doyman, S., \& Yumru, H. (2020). An exploration of students' perceived sources of speaking anxiety. International Journal of Media Culture and Literature, 6(2), 189-199.

Fathiyah, H. I., Amiruddin, A. N., Khan, F., \& Venzano, F. (2020). Language Learning Strategies (LLS) used by Malaysian, Pakistani, and Italian ESL learners: Comparing to Indonesian EFL Learners. English Language in Focus (ELIF), 2(2), 87-96.

Gani, S. A., Fajrina, D., \& Hanifa, R. (2015). Students' learning strategies for developing speaking ability. Studies in English Language and Education, 2(1), 16-28. https://doi.org/10.24815/siele.v2i1.2232

Hall, J. K. (2001). Methods for teaching foreign languages. Upper Saddle River, NJ: Prentice Hall

Hoa, T. M., \& Thao, P. T. M. (2020). Speaking learning strategies employed by English-majored sophomores at college of foreign economic relations. VNU Journal of Foreign Studies, 36(3).

Husna, H. A. U. (2021). The relationship between the students' English speaking skills and their closeness to English. Language Circle: Journal of Language and Literature, 15(2), 229-240.

Javed, M., \& Ali, A. (2018). Analyzing the Use of Language Learning Strategies among high and low achievers. Journal of Research \& Reflections in Education (JRRE), 12(1).

Khatib, F. M. M., Rubaai, N., \& Thangaveloo, R. M. (2021). Perceived self-efficacy of speaking skills among English as a Second Language (ESL) technical college students. Asian Journal of Research in Education and Social Sciences, 3(1), 60-71.

Malihah, N. (2010). The effectiveness of speaking instruction through task-based language teaching. Register Journal, 3(1), 85-101

Masduqi, H. (2016). Integrating receptive skills and productive skills into a reading lesson. In Proceeding of the International Conference on Teacher Training and Education, 2(1), 507-511.

Masuram, J., \& Sripada, P. N.(2020). Developing speaking skills through task-based materials, Procedia Computer Science, 172, 60-65.

Mridha, M. M., \& Muniruzzaman, S. M. (2020). Developing English speaking skills: Barriers faced by the Bangladeshi EFL learners. Englisia: Journal of Language, Education, and Humanities, 7(2), 116-131.

Muamar, M., Hente, M.A., \& Arid, M. (2019). Faktor-faktor yang mempengaruhi kemampuan berbicara siswa semester empat program studi pendidikan bahasa Inggris di Universitas Muhammadiyah Palu. Jurnal Kolaboratif Sains.

Liandika, A., Nurhasanah, A., \& Amalia, S. (2021). The Correlation between students' learning attitude and their speaking confidence at SMK Negeri 1 Kota Jambi (Doctoral 
dissertation, UIN Sulthan Thaha Saifuddin Jambi)

O'Malley, J. M., \& Chamot, A. U. (1990). Learning Strategies in Second Language Acquisition. New York: Cambridge University Press.

Oxford, R. L. (1990). Language learning strategies: What every teacher should know. New York, NY: Newbury House/ Harper \& Row 3.

Rao, P. S. (2019). The importance of speaking skills in English classrooms. Alford Council of International English \& Literature Journal (ACIELJ) 2.2 (2019): 6-18.

Saputra, E., \& Subekti, N. (2017). A study of the speaking learning strategies used by English Education Department students. JELLT (Journal of English Language and Language Teaching), 1(1), 1-8.

Saud, W. I. (2019). A contrastive analysis of ESL and EFL learning strategies. Journal of Language Teaching and Research, 10(2), 311-321.

Subramaniam, B., \& Palanisamy, K. (2014). The Usage of Language Learning Strategies in Malaysian Private Secondary Schools. Advances in Language and Literary Studies, 5(4), 96-101. http://www.journals.aiac.org.au/index.php/alls/article/view/437/374

Syafitri, A., Yundayani, A., \& Kusumajati, W. K. (2019). Hubungan antara kepercayaan diri siswa terhadap kemampuan berbicara Bahasa Inggris. 1-8. https://jurnal.stkipkusumanegara.ac.id/index.php/semnara2019/article/download/3 $34 / 299$.

Tran, T. Q., \& Tran, T. N. P. (2021). Vietnamese EFL high school students' use of self-regulated language learning strategies for project-based learning. International Journal of Instruction, 14(1).

Zare, P. (2012). Language learning strategies among EFL/ESL learners: A review of literature. International Journal of Humanities and Social Science, 2(5), 162-169. 
INTERNATIONAL JOURNAL OF ACADEMIC RESEARCH IN BUSINESS AND SOCIAL SCIENCES Vol. 11, No. 6, 2021, E-ISSN: 2222-6990 @ 2021 HRMARS

\section{Appendix (Speaking Learning Strategies Survey Questionnaires)}

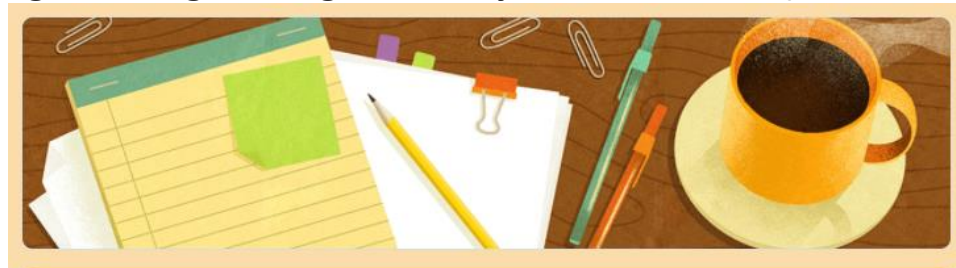

Speaking Learning Strategies Survey Questionnaire

*Required

Strategies to Practise Speaking / Strategi Berlatih Bercakap

Choose the best answer that reflects your speaking practices. / Pilih jawapan yang paling sesuai mewakili amalan berbahasa Inggeris anda.

1. Practise saying new expressions to myself. / Berlatih meluahkan ekspresi baharu terhadap diri sendiri. *

Inever use the strategy

I seldom use the strategy. (1-2 times a week)

I sometimes use the strategy. (3-4 times a week)

I often use the strategy. (More than 4 times a week)

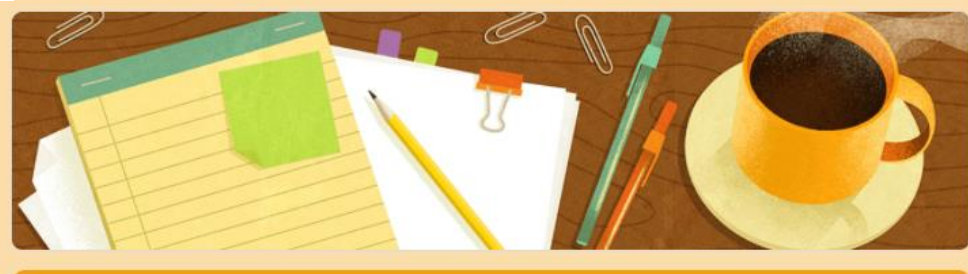

Speaking Learning Strategies Survey Questionnaire

Kindly answer all the questions in the survey. Thank you!

*Required

Full Name / Nama Penuh *

Your answer

Class / Kelas *

2 Agama

2 Arif

2 Bestari 
 Inggeris. *
I never use the strategy.
I seldom use the strategy. (1-2 times a week)
I sometimes use the strategy. (3-4 times a week)
I often use the strategy. (More than 4 times a week)

2. Practise new grammatical structures in different situations to build my confidence level in using them. / Berlatih struktur tatabahasa baharu dalam pelbagai situasi untuk membina tahap keyakinan diri dalam menggunakan Bahasa

3. Think about how a native speaker might say something and practise saying it that way. / Memikirkan cara orang yang bahasa utamanya Bahasa Inggeris menyebut sesuatu dan berlatih menyebutnya sebegitu. *

I never use the strategy.

I seldom use the strategy. (1-2 times a week)

I sometimes use the strategy. (3-4 times a week)

I often use the strategy. (More than 4 times a week)

Back Next

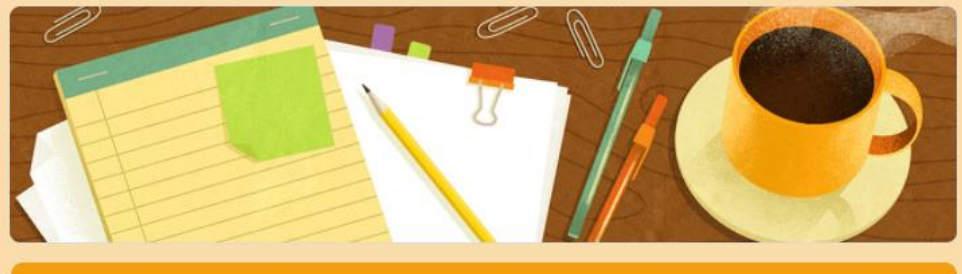

\section{Speaking Learning Strategies Survey} Questionnaire

*Required

Strategies to Engage in Conversations / Strategi Melibatkan Diri dalam Perbualan

What do you do when you have a conversation with someone? Choose the best answer that reflects your strategies to engage in conversations. / Apakah yang anda lakukan ketika berkomunikasi dengan seseorang? Pilih jawapan yang paling sesuai mewakili strategi anda dalam perbualan.

4. Plan out what I want to say in advance. / Merancang terlebih dahulu apa yang saya ingin cakap. *
Inever use the strategy
I seldom use the strategy. (1-2 times a week)
I sometimes use the strategy. (3-4 times a week)
I often use the strategy. (More than 4 times a week) 
INTERNATIONAL JOURNAL OF ACADEMIC RESEARCH IN BUSINESS AND SOCIAL SCIENCES Vol. 11, No. 6, 2021, E-ISSN: 2222-6990 @ 2021 HRMARS

5. Ask questions as a way to be involved in the conversation. / Bertanya soalan sebagai satu cara untuk terlibat dalam perbualan. *

I never use the strategy.

I seldom use the strategy. (1-2 times a week)

I sometimes use the strategy. (3-4 times a week)

I often use the strategy. (More than 4 times a week)

6. Able to continue the conversation. / Mampu menyambung perbualan. *

I never use the strategy.

I seldom use the strategy. (1-2 times a week)

I sometimes use the strategy. (3-4 times a week)

I often use the strategy. (More than 4 times a week)

7. Try topics even when they aren't familiar to me. / Mencuba perbualan topik yang tidak biasa. *

I never use the strategy.

I seldom use the strategy. (1-2 times a week)

I sometimes use the strategy. (3-4 times a week)

I often use the strategy. (More than 4 times a week)

8. Encourage others to correct errors in my speaking. / Menggalakkan orang lain untuk membetulkan kesalahan ketika bercakap. *

I never use the strategy

I seldom use the strategy. (1-2 times a week)

I sometimes use the strategy. (3-4 times a week)

I often use the strategy. (More than 4 times a week)

9. Try to imitate native speakers' language patterns used in conversation through any possible exposure. / Mencuba untuk meniru gaya bahasa yang digunakan dalam perbualan oleh orang yang bahasa utamanya Bahasa Inggeris melalui mana-mana pendedahan. *

I never use the strategy.

I seldom use the strategy. (1-2 times a week)

I sometimes use the strategy. (3-4 times a week)

I often use the strategy. (More than 4 times a week) 


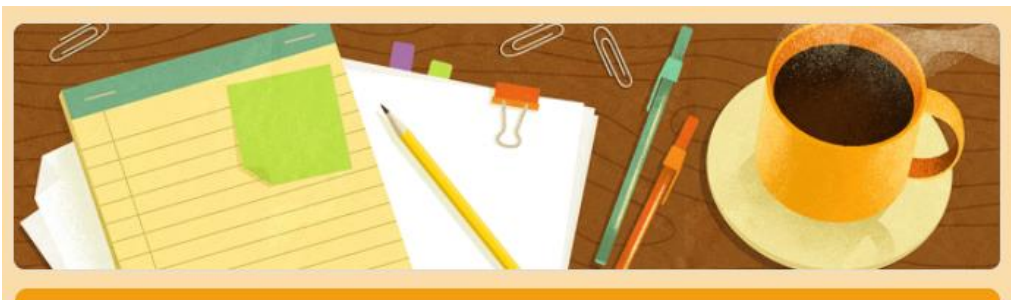

\section{Speaking Learning Strategies Survey Questionnaire}

*Required

Strategies for When I Can't Think of a Word or Expression / Strategi Apabila Saya Tidak Dapat Memikirkan Sesuatu Perkataan Atau Ekpresi

What do you do when you are stuck when speaking in English? Choose the best answer that reflects your speaking practices. / Apakah yang anda lakukan apabila anda buntu ketika bercakap dalam Bahasa Inggeris? Pilih jawapan yang paling sesuai mewakili amalan bercakap anda.

10. Ask for help from my conversational partner. / Minta bantuan daripada orang yang sedang kita berbual. *
I never use the strategy.
I seldom use the strategy. (1-2 times a week)
I sometimes use the strategy. (3-4 times a week)
I often use the strategy. (More than 4 times a week)

11. Look for a different way to express the idea, like using a synonym. / Menerokai cara berlainan untuk meluahkan idea, seperti menggunakan perkataan yang sama maksud. *

I never use the strategy.

I seldom use the strategy. (1-2 times a week)

I sometimes use the strategy. (3-4 times a week)

I often use the strategy. (More than 4 times a week)

12. Use words from my own language, but say it in a way that sounds like words in the target language. / Menggunakan perkataan daripada bahasa utama sendiri, tetapi menyebutnya seperti bahasa yang disasarkan. *
I never use the strategy.
I seldom use the strategy. (1-2 times a week)
I sometimes use the strategy. (3-4 times a week)
I often use the strategy. (More than 4 times a week) 
INTERNATIONAL JOURNAL OF ACADEMIC RESEARCH IN BUSINESS AND SOCIAL SCIENCES Vol. 11, No. 6, 2021, E-ISSN: 2222-6990 @ 2021 HRMARS

13. Make up new words or guess if I don't know the right ones to use. / Membina perkataan baharu atau meneka jika saya tidak pasti perkataan yang sepatutnya digunakan. *

I never use the strategy.

I seldom use the strategy. (1-2 times a week)

I sometimes use the strategy. (3-4 times a week)

I often use the strategy. (More than 4 times a week)

14. Use gestures as a way to try and get my meaning across. / Menggunakan gaya badan sebagai satu cara untuk mencuba menyampaikan maksud. *

I never use the strategy.

I seldom use the strategy. (1-2 times a week)

I sometimes use the strategy. (3-4 times a week)

I often use the strategy. (More than 4 times a week)

15. Switch back to my own language momentarily if I know that the person I'm talking to can understand what is being said. / Tukar kepada bahasa utama sendiri sekali-sekala jikalau saya tahu orang yang saya tengah berbual faham apa yang saya akan cakap. *

I never use the strategy.

I seldom use the strategy. (1-2 times a week)

I sometimes use the strategy. (3-4 times a week)

I often use the strategy. (More than 4 times a week) 